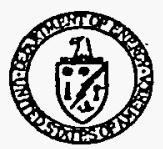

\title{
Using the Data Quality Objectives Process in Risk Assessment
}

\begin{abstract}
BACKGROUND: The Environmental Protection Agency's (EPA) Quality Assurance Management Staff has developed a systematic process, the Data Quality Objectives (DQO) process, as an important tool for assisting project managers and planners in determining the type, quantity, and quality of environmental data sufficlent for environmental decision-making. This Information brief presents the basic concepts of, and Information requirements for using the DQO process to plan the collection of the necessary environmental data, to support the performance of human health risk assessments under the Comprehensive Environmental Response, Compensation, and Llability Act (CERCLA) or Resource Conservation and Recovery Act (RCRA). The goal of the DQO process is to identify the type, quality, and quantity of data required to support remedial action decisions which are based on risk assessment and its assoclated uncertaintles. The DQO process consists of a number of discrete steps. These steps include a statement of the problem and the decision to be made, Identifying inputs to the decision (data quality and quantity for the risk assessment), developing a decision rule, and optimizing the design for data collection. In defining the data for input into the decision, a Site Conceptual Exposure Model (SCEM) should be developed to identify the existing or potential complete exposure pathways. To determine the data quality for use in the risk assessment, the DQO team must assist the declsion-maker to define the acceptable level of uncertainty for making site-specific decisions. To determine the quantity of data needed, the DQO team utilizes the established target cleanup level, previously collected data and variability, and the acceptable errors. The results of the DQO process are qualitative and quantitative statements (DQOs) that define the scope of risk assessment data to be collected to support a defensible site risk management decision.
\end{abstract}

STATUTES:

Comprehensive Environmental Response, Compensation and Llability Act (CERCLA), as amended by the Superfund Amendments and Reauthorization Act (SARA) and the Resource Conservation and Recovery Act (RCRA), as amended by the Hazardous and Solid Waste Amendments (HSWA) and the Federal Facility Compliance Act (FFCA).

REGULATIONS: 40 CFR 300.430(b) \& (d)(Scoping; Remedial Investigation; and Baseline Risk Assessment)(55 FR 8660, March 8, 1990) and 40 CFR 264.510 to 264.522, Subpart S proposed rule (55 FR 30798, July 27, 1990)

REFERENCES: 1. "Guidance for Data Useability In Risk Assessment," Interim Final, EPA540/G-901008 (October, 1990).

3. "Guidance for Planning for Data Collection in Support of Environmental Decision Making Using the Data Quality Objectives Process," Interim Final, EPA QAVG-4 (August, 1993).

4. "Data Quality Objectives Process for Superfund," Interim Final, EPA-540-G-93-071 (September, 1993).

5. "Remedial Investigation/Feasibility Study (RIFS) Process, Elements, and Techniques," DOE EH-94007658 (December, 1993).

\section{What are Data Quality Objectives?}

DQOs are qualitative and quantitative statements that define the type, quality, and quantity of data necessary to support defensible risk management decision-making. DQOs are used to develop an effective sampling plan which avoids the collection of data that are inconsequential to decision-making.

\section{What is the DQO Process?}

- DQ́O's are developed before data are collected, as part of sampling program design. The outputs from each step of the process result in the DQOs, which are statements that:

- Clarify the objective of the data collection effort;

- Specify how the data will be used to support the'risk management decision being addressed;

- Define the most appropriate type of data to collect;

- Specify acceptable levels of decision errors that will be used as the basis for establishing the quantity and quality of data needed (a decision error rate is the probability of making an incorrect decision based on data that inaccurately estimate the true conditions at the site); and

- Specify the quantity and quality of data to be collected.

- The DQO Process consists of the following seven steps, which are sequential and reiterative:

Step 1: State the Problem - Concisely describe the problem to be studied.

Example: Chromium has been detected in soil near the edges of a former waste storage pad. Past site activities did involve waste materials containing chromium. Continued industrial use of the site is planned.

Step 2: Identify the Decision - Identify the decision that will solve the problem using data.

Example: Decide whether and how to remediate contaminated soil to protect human health and the environment.

Step 3: Identify the Inputs to the Decision - Identify the information needed and the resulting measurements that need to be taken in order to support the decision. These include sources for each item of information and information 
needed to establish protective concentration level Example:

- A Site Conceptual Exposure Model (SCEM) showing that ingestion of contaminated soil by on-site workers is the primary exposure pathway;

- Sample data to confirm the SCEM (e.g., Toxicity Characteristic Leaching Procedure (TCLP) data to show that leaching to groundwater is insignificant or whether hazardous waste characteristic is exhibited;

- Soil sample data to define "hot spots" and the extent and magnitudo of potential worker exposure;

- Chromium speciation analyses to determine the ratio of trivalent to hexavalent chromium in soil, since their toxicity factors are significantly different;

- Risk goals to be achieved (e.g., cancer risk no greator than $10^{-4}$ and . hazard index no greater than 1):

- Risk assessment to back-calculate soil concentrations that will result in achievement of risk goals; and

- Confimation samples analyzed by analytical methods of sufficiently low detection limits to show that remediation is complete.

Step 4: Define the Study Boundaries - Specify the conditions (time periods, spatial areas, and situations) to which the decisions will apply and within which the data will be collected. Example:

- Risk goals will be met for current and future land use scenarios;

- All site sample data used must have been collected within "a specified period of time:

- Workers are assumed to be exposed to only the top one foot of soil; and

- Background samples must be taken within one mile of the site in soils of similar nature to site soil.

Step 5: Develop a Decision Rule - Define the conditions by which the decision-maker will choose among altemative risk management actions. This is usually in the form of an "if...then..." statement. Example: If the 95 percent upper confidence limit of the average concentration of any contaminant of concem within the top one foot of soil is greater than its risk-based cleanup level, then remediate the soil or institute containment measures.

Step 6: Specify Acceptable Limits on Decision Errors Define, in statistical terms, the decision-maker's acceptable error rates based on the consequence of making an incorrect decision.

Example: The null hypothesis for a site, as defined by EPA in its DQO guidance, assumes that as a baseline condition, the site is contaminated. Acceptance of this hypothesis will lead to remediation, while rejecting the hypothesis will serve as a basis for site close-out with no further action. In this case, the more severe decision error in terms of human health risk, would be to reject the null hypothesis, i.e., to leave a contaminated site unremediated. The consequence of an error in the opposite direction, (i.e., accept the null hypothesis and remediate a clean site) is less severe in terms of the potential health impacts, "and allows for a greater margin of error. For step 6 of the DQO process, acceptable error rates for either situation must be assigned. Typically, error rates are as high as $20 \%$ for incorrectly accepting the null (i.e., remediate a clean site), and as low as $1 \%$ to $5 \%$ for incorrectly rejecting the null (i.e., no further action taken at a contaminated site).

Step 7: Optimize the Design - Evaluate the results of the previous steps and develop the most resourceefficient design for data collection that meets all DQOs.

Example: The DQOs should be súmmarized in a matrix table; for each medium, highlight the objective, prioritized data uses, analytical level (e.g., level III or better for a baseline risk assessment), contaminant of concem, level of concem (e.g., target cleanup level), required detection limit, and critical sample locations/identity). The DQO report would present the results of each step, including statistical calculations to determine the number of samples needed (with consideration of any existing data) to meet the acceptable limits on decision emors specified in Step 6.

\section{When should the DQO Process be used?}

- During the planning stage of any study that requires data collection, before the data are collected;
- Where data collection programs or likely risk management actions will require substantial resources;

- As a vehicle to develop consensus agreements with regulatory decision-makers and stakeholders on what data to collect and how it will be used; and

- After data collection, to guide the use of data in the decision process and to control requests for additional data collection. The DQO process evolves and can be modified as more information becomes available. For example, DQOs for the $\mathrm{RI}$ or $\mathrm{RFI}$ should take into consideration removal actions (accomplished or to be taken) in explaining data collection design and use.

\section{What is the role of risk assessment in the DQO process?}

- Development of SCEM to establish significant media, pathways, and receptors;

- Identification of chemicals of concern;

- Development of risk-based cleanup levels;

- Specification of data needed to support risk assessment, including maximum detection limits needed to ensure that action levels can be met; and

- Development of points of compliance where cleanup levels must be achieved (i.e., locations, depths and media where cleanup levels must be met to achieve risk goals) and to define the area(s) of contamination based on established or calculated protective concentration levels

\section{How can the DQO Process improve the collection of data for site risk assessment?}

- Clearly defines the role of risk assessment in the decision process, including how risk assessment results will be used to make decisions, what data are needed to support the risk assessment, and how that data will be used; and

- Ensures that adequate and appropriate data will be collected to support risk assessment needs, including:

- data of sufficient quantity and quality to calculate reliable estimates of exposure point concentrations (e.g., 95\% upper confidence limits of average concentrations) at appropriate locations:

- data collected at locations and in media to confirm that particular media or pathways are or are not significant;

- detection limits low enough to allow comparison to risk-based action levels:

- background level data to differentiate the site from other possible sources and to use as alternative action levels for naturally-occurring inorganic constituents; and

QAVQ samples and qualifiers needed to screen data for useability in risk assessment and select the chemicals of concern. 


\section{DISCLAIMER}

This report was prepared as an account of work sponsored by an agency of the United States Government. Neither the United States Government nor any agency thereof, nor any of their employees, make any warranty, express or implied, or assumes any legal liability or responsibility for the accuracy, completeness, or usefulness of any information, apparatus, product, or process disclosed, or represents that its use would not infringe privately owned rights. Reference herein to any specific commercial product, process, or service by trade name, trademark, manufacturer, or otherwise does not necessarily constitute or imply its endorsement, recommendation, or favoring by the United States Government or any agency thereof. The views and opinions of authors expressed herein do not necessarily state or reflect those of the United States Government or any agency thereof. 


\section{DISCLAIMER}

Portions of this document may be illegible in electronic image products. Images are produced from the best available original document. 